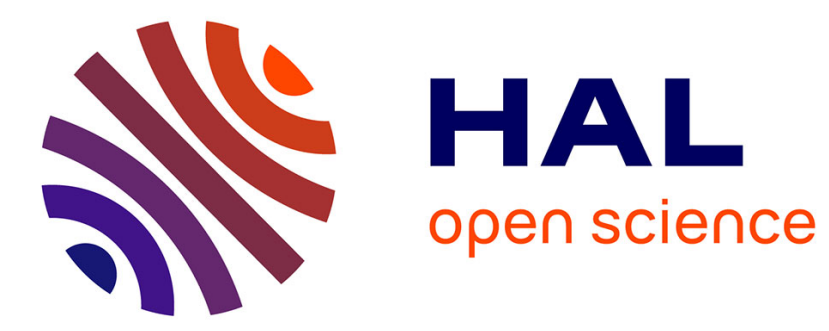

\title{
Quartz Ore Beneficiation by Reverse Flotation for Silicon Production
}

Sidali Medjahed, Abdelkrim Kheloufi, Ema Bobocioiu, Aissa Kefaifi, Fouad Kerkar, Kheirreddine Lebbou

\section{- To cite this version:}

Sidali Medjahed, Abdelkrim Kheloufi, Ema Bobocioiu, Aissa Kefaifi, Fouad Kerkar, et al.. Quartz Ore Beneficiation by Reverse Flotation for Silicon Production. Silicon, 2020, 10.1007/s12633-020-00790-x . hal-03000565

\section{HAL Id: hal-03000565 \\ https://hal.science/hal-03000565}

Submitted on 4 Feb 2021

HAL is a multi-disciplinary open access archive for the deposit and dissemination of scientific research documents, whether they are published or not. The documents may come from teaching and research institutions in France or abroad, or from public or private research centers.
L'archive ouverte pluridisciplinaire HAL, est destinée au dépôt et à la diffusion de documents scientifiques de niveau recherche, publiés ou non, émanant des établissements d'enseignement et de recherche français ou étrangers, des laboratoires publics ou privés. 


\title{
Quartz Ore Beneficiation By Reverse Flotation For Silicon Production
}

\author{
Sidali MEDJAHED ${ }^{1}$, Abdelkrim KHELOUFI ${ }^{1}{ }^{*}$, Ema BOBOCIOIU $^{2}$, Aissa KEFAIFI ${ }^{1}$, \\ Fouad Kerkar ${ }^{1}$, Kheirreddine LEBBOU $^{3}$ \\ *Corresponding author: Abdelkrim Kheloufi kheloufi@yahoo.co.uk \\ ${ }^{1}$ Centre de Recherche en Technologie des semi-conducteurs pour l'Energétique, Bd Frantz Fanon \\ BP 140 Alger, 7 Merveilles 16038 Algérie, \\ ${ }^{2}$ Ecole Normale Supérieure de Lyon, 46, Allée d'Italie 69364 Lyon Cedex 07, \\ ${ }^{3}$ Université Claude Bernard Lyon 1, CNRS, Institut Lumière Matière, F-69622, Villeurbanne, \\ France.
}

\begin{abstract}
In this work the reverse flotation as beneficiation process for high-purity silica valorization from Draissa quartz deposits (Algeria) is studied as a potential raw material for photovoltaic silicon production and alse for starting charge for crystal growth material for a large wide of application such laser and scintillation.

The samples are examined investigated by optical microscopy, secondary ion mass spectroscopy, X-ray fluorescence and Raman spectroscopy. The microscopic investigations detect solid impurities such as alkaline and plagioclase feldspars, micas and iron oxides. The analyzed silica shows well-developed crystals areas, delimited by microcrystalline regions. Impurities are predominantly located in low quartz granulometry $(50-100 \mu \mathrm{m})$. The XRF results highlight 93.63wt.\% $\mathrm{SiO}_{2}, 0.16$ wt.\%, $\mathrm{Fe}_{2} \mathrm{O}_{3}, 0.171$ wt.\% Cl, 0.15wt.\% $\mathrm{CaO}, 5.74$ wt.\% $\mathrm{Al}_{2} \mathrm{O}_{3}, 0.074$ wt.\% $\mathrm{K}_{2} \mathrm{O}, 0.001 \%$ wt $\mathrm{CdO}, 0.006 \%$ wt. $\mathrm{SnO}_{2}$. However, these results remain insufficient for predestined use of this material faw quartz directly. A preliminary enrichment using reverse flotation process improves the silica purity up to $99.6 \%$ and removes the major impurities, which
\end{abstract}


is suitable intermediate technological product able for silicon production and optical application demain.

Keywords Draissa, Quartz, Characterization, Flotation, Silica, Silicon

\section{Introduction}

Reliable and unhindered access to silica is a growing concern. It is of high importance to the industry and of high risk associated with their supply. Algeria is thought to be one of the suppliers of natural resources and especially silica raw material. Its strategy vision is to develop raw materials into a major strength for industry such us pure silica for photovoltaic silicon production.

The growth of photovoltaic (PV) industry is mainly based on silicon solar cells and reducing the cost of silicon wafers [1]. Due to the advantages of low production cost and relatively high conversion efficiency, multicrystalline silicon has become the main material used for PV.

High level purity silica is a strategic mineral with a large wide of applications in high-tech industry that include semiconductors, optics, electro-magnetic materials, starting charge for crystal growth, synthesis of laser crystals and also the elaboration of silicon single crystals for gravitational waves detectors [1-4].

Very high purity quartz deposits are extremely rare. Quite often the quartz needs a prior enrichment to be used for advanced high-tech applications.

In industrial minerals, quartz is often associated with feldspar, and other silicates and oxides minerals which These last affect strongly affect their properties and performance [3]. High purity quartz is frequently used for photovoltaic silicon and some optical applications. In this case, the best performance comes from high pure silica with low content of chemical impurities, mainly $\mathrm{Fe}, \mathrm{Al}, \mathrm{Ti}, \mathrm{K}, \mathrm{Na}, \mathrm{Cr}, \mathrm{Ni}, \mathrm{Mn}$ and $\mathrm{Cu}$ [1-5]. 
In this context, the eontent of impurities must to be removed partially or completely using physical, physicochemical or chemical appropriate methods, based on their mineralogical studies and also on their quantity and their distribution in the ore [5-11]. Therefore, decreasing and removing impurities as much as possible-from the quartz by an effective, environment-friendlier method and understanding its mechanism is particularly critical. In this case, Up to now, considerable efforts have been devoted to these targets [7, 12-22].

In the Algerian context, in order to secure the supply of raw material for the PV industry, the production of solar-grade silicon remains imperative. So, finding looking for a technical, economic and environmental solution to control silica production has become essential for a potential deposit such Draissa $94 \mathrm{wt} \% \mathrm{SiO}_{2}$. Therefore, it is imperative to develop the silica beneficiation processes to valorize this abundant natural resource and prepare, at the same time, the basics of national solar industry.

In recent years, one of the most promising processes that have been noticed is the enrichment of silica by flotation method, in which particulate matter (minerals) is separated from the gangue thanks to chemical reactants by gas bubbles immersed in water. In this context, flotation as beneficiation process is used due to its high efficiency to reach required high purity silica. So far, a particular interest is given mainly to reverse flotation over direct flotation as a dynamic multiphasic and high efficiency selective process of quartz beneficiation. Reverse flotation process is used to separate minerals impurities as concentrate from valuable mineral as tailings. In our case, impurities are presented by mica, dolomite, barite, hematite, iron oxides and feldspar. In conventional flotation, the mineral particle values are hydrophobic while the gangue particles are hydrophilic. The relatively small gangue particles and some middling particles are entrained (or entrapped) along with the collected particles in the concentrate. In reverse flotation inversely, the gangue particles are made hydrophobic and particles mineralized are made hydrophilic 
(depressed). The gangue particles and some middling particles are collected and thus removed in the concentrate, while some valuable minerals might be entrained along with them $[23,24]$. The entrainment of quartz particles (along with some middling), in our case occurs to a lesser extent than the entrainment of gangue particles in froth flotation due to the existing of smaller mass flux, and the fact that minerals particles generally have a larger average particle size than the gangue. Consequently, the grade of the obtained quartz should be better than that of conventional flotation.

In this work, the Draissa quartz deposit from Bechar Provence (south west region of Algeria) was studied for its useful used.

The Draissa deposits are located in Ougarda Mountains, in sedimentary terrains of Paleozoic age (Cambrian - Ordovician) (Fig. 1). They are represented by quartz sandstone associated with large hydrothermal barite veins, which have already been subjected to previous exploitations. The silica material represents the gangue of the barite mineralization and it is estimated at about 850 million metric tons [25]. This kind of quartz material should be crucial to Algeria and African economy. It will form a strong industrial base, producing a broad range of goods and applications used in modern technologies.

\section{Fig. 1 is here}

The preliminary investigations on this quartz deposit show that can be used as potential sources for photovoltaic and optical applications.

\section{Materials and Methods}


Samples from the Draissa deposit are collected from different pits in the area to represent as much as possible the actual deposits. A Rigorous sampling was performed with the help of experts from the Algerian mining company of barite "Albaryte".

First the samples were collected, crushed, well mixed and quartered. After they were examined using optical microscopy in both transmitted and reflected lights to regroup the necessary information for choosing the adequate technological purification process.

To confirm certain micron-sized mineralogical phases, microscopic observations are supplemented with Raman analysis. The Raman analyses are realized in the Laboratory of Geology of Lyon (ENS) using a Jobin-Yvon Horiba LabRam HR800 VIS spectrometer, equipped with focal microscope and CCD detector. Wavelengths at 514 and $532 \mathrm{~nm}$ and objective lenses of $50 \times$ are also used $[1,26]$.

Information-regarding the textural relations between particles, the distribution of intragranular cracks, the purity of the quartz or its crystallization conditions is obtained using cathodoluminescence techniques performed in laboratory of Mineralogy (Lithos Center) at Bucharest University. A device with cold cathode (CL 8200MK 3A), 0.5 Torr average vacuum pressure, $15-17 \mathrm{kV}$ voltage, $350-400 \mathrm{~mA}$ current intensity, mounted on a Nikon E400 optical microscope is employed.

The chemical composition of the samples is analyzed by X-ray fluorescence (XRF) using Panalytical Philips Magix Pro 2440 spectrometer. The XRF analyzes are carried out in the laboratory of physics at Blida University, Algeria.

In order to detect very low concentrations of minor elements present in the silica, secondary ion mass spectrometry (SIMS) is used. The SIMS analysis can provide concentration profiles that cover depths ranging from a few of nanometers to several of microns, as well as mass spectra up 
to 300 uma. The SIMS profiles are obtained by an IMS 4F-E7 mass spectrometer (Cameca, CRTSE-Algeria) with $\mathrm{O} 2+$ and Cs+ primary ion sources. While SIMS is typically a qualitative methodology, it can be applied in a semi-quantitative manner as long as high-quality standards are available.

In order to remove the impurities from quartz and increase its purity up to the required value of $99 \% \mathrm{SiO}_{2}$, a reverse flotation process is used. The experiments are carried out in the laboratory of mineral processing at Ecole Nationale Polyechnique of Algiers using a DENVER laboratory flotation cell D-12 machine, using 4L cell volume (Fig. 2). The flotation is carried out in three stages, where the mica is removed in the first flotation stage followed by the iron oxides in the second one and finally the feldspar is separated from quartz in the third stage.

The obtained concentrates of each stage are removed as impurities. Therefore the obtained tailings are treated successively until achieving the high pure silica. During each flotation stage the concentrate is obtained and collected after 2 min intervals after addition of required collector in the pulp. The pulp density is adjusted and conditioned for the needed $\mathrm{pH}$

First, about $2.5 \mathrm{~kg}$ of the quartz rocks with $300 \mathrm{~mm}$ average size is washed, crushed, ground and classified. Before the flotation, the feed is deslimed, removing any fine clay minerals present in the raw mineral. After, desliming and classification the pulp underflow less than $100 \mu \mathrm{m}$ carried out the first stage of flotation process using Duodecyclamine (DDA) at $99 \%$ concentration as a collector and sulfuric acid $\left(\mathrm{H}_{2} \mathrm{SO}_{4}\right)$ as gangue depressor and $\mathrm{pH}$ regulator. The frother $(1 \% \mathrm{w} / \mathrm{v})$ is added in the pulp and the system is permitted to be mixed for the conditioning time of 3 min after which air is introduced through a rotor located at the bottom of the cell. The air flow rate is automatically controlled by a needle valve adjusted depending upon the speed of the stirrer which is used to keep the particles in suspension. After first stage flotation, mica concentrate is obtained and weighed (concentrate 1). 
In the second stage, residual iron minerals, such as ilmenite and mostly hematite, are removed using Sodium oleate $(\mathrm{NaOL})(100-300 \mathrm{~g} / \mathrm{t})$ as a collector. Between the first and second stage the pulp is subjected to dewatering and washing. The dewatering is done in a spiral laboratory classifier. The washing is used as an additive operation in order to remove the residual reagents in the tailings. As the same conditions cited for the first stage and after adding sodium oleate NaOL and pine oil, the iron minerals are removed as concentrate 2.

In the $3^{\text {rd }}$ stage flotation, the feldspar is activated by HF, collected by DDA and frothed using pine oil. The use of fluoride acid (HF) at $40 \%$ is to activate the feldspar and also to suppress at the same time the quartz. The foam obtained is removed mechanically and weighed as concentrate 3. A dosage about $300 \mathrm{~g} /$ ton of DDA is used. The obtained residual product is high grade quartz.

\section{Fig. 2 is here}

Contact angle measurement tests are carried out on the surface of mica, hematite, feldspar and quartz at different pulp $\mathrm{pH}$ conditions.

Z-potential in the third stage is established for comparing the rate of hydrophobicity between feldspar and quartz using HF.

At the end of each test the results of flotation were evaluated on the impurities recovery rate of the obtained concentrates after enrichment i.e hematite, mica and feldspar. The recovery rate is the ratio expressed in $\%$ of the weight of the concentrate to the feed weight as shown in equation 


$$
\mathrm{y}=\frac{C}{A} \times 100, \%
$$

(Equation 1)

where,

y - Recovery rate; C- Weight concentrate; A - Weight of feed.

\section{Results and discussion}

\subsection{Mineralogical and chemical characterization of Draissa Deposit}

Samples collected from the investigated region are mainly represented by sandstones with high degree of compaction. Under the effect of diagenesis and fluid circulation, the sandstone is partially recrystallized in quartzite. The mineralogical composition fits the sandstone at the limit between "quartz sandstone" and "subarkose", with 90\% quartz and 10\% feldspar or lithic elements (Fig. 3). The quartz grains are usually angular with various sizes ranging between $\sim 10 \mu \mathrm{m}$ and $1.5-2 \mathrm{~mm}$, rarely reaching centimeter dimensions. Areas with well-developed crystals alternate with areas with reduced granulometry (Fig. 3a).

Cathodoluminescence images highlight the presence of the overgrowth crowns of quartz granoclasts. The central area is characterized by quite important luminescence while, in the

\section{Fig. 3 is here}

overgrowth zone the luminescence is absent (Fig. 3b). The presence or absence of luminescence in the quartz may reflects its purity. Thus, grains without luminescence can be considered poor in trace elements or structural defects [27]. The presence of quartz granules is noted, with graphical and granophyric structures (intergrowths between quartz and alkali feldspar) derived from the erosion of magmatic rocks (Fig. 3c). However, the quartz is not only present like granoclasts. It is 
also developing like autigenetic cement or recrystallizations (Fig. 3d). These recrystallizations are very important because they can entail a further purification of quartz granules [28].

In association with the quartz, other mineral phases such as feldspars, mica, carbonates, sulfates or Fe oxides and hydroxides are found. All these mineral phases represent "impurities" of the rock that will have to be removed during the quartz purification stages.

Thus, some areas of the sandstone are relatively rich in feldspar most of them having an advanced degree of alteration in clay minerals (sericite, kaolinite, etc.), but fresh crystals can also be found (Fig. 3e). The polysynthetic twins of plagioclases $\left(\mathrm{NaAlSi}_{3} \mathrm{O}_{8}-\mathrm{CaAl}_{2} \mathrm{Si}_{2} \mathrm{O}_{8}\right)$ or the multipletwinned crystals of microcline $\left(\mathrm{KAlSi}_{3} \mathrm{O}_{8}\right)$ are recognized (Fig. 3f). Most of the feldspar crystals or clay material seems to be associated with areas where the quartz has low grain sizes.

Microscopic investigations also reveal the presence of muscovite crystals $\left(\mathrm{KAl}_{2}\left(\mathrm{AlSi}_{3} \mathrm{O}_{10}\right)(\mathrm{OH}, \mathrm{F})_{2}\right)$ with sizes from $10 \mu \mathrm{m}$ to $1 \mathrm{~mm}$, mostly between $50 \mu \mathrm{m}$ and $100 \mu \mathrm{m}$. Significant quantities of carbonate may also be present as impurities in the rock. Raman analyses and cathodoluminescence $(\mathrm{CL})$ investigations attest the presence of calcite $\left(\mathrm{CaCO}_{3}\right)$ and dolomite $\left(\mathrm{CaMg}\left(\mathrm{CO}_{3}\right)_{2}\right)$ that develop as secondary minerals in cavities or cracks (Fig. 3g). The intense red color of the carbonates in the CL confirms the presence of $\mathrm{Mn}$ as trace element in the carbonate structure. When the degree of compaction of the rock is less important, the presence of a matrix consisting of clay material and carbonates in association with $\mathrm{Fe}$ oxides and a fine quartz fraction is noted (Fig. 3h). Also, some quantities of barite are detected using Raman spectroscopy (Fig. 4). Barite $\left(\mathrm{BaSO}_{4}\right)$ is present as granoclasts with dimensions around 
several hundred micrometers. The iron oxides such as hematite $\left(\mathrm{Fe}_{2} \mathrm{O}_{3}\right)$ develop predominantly in fracture areas due to the circulation of hydrothermal fluids.

Quartzite veins are rich in $\mathrm{Fe}$ oxides and hydroxides associated with $\mathrm{Cu}$ sulfides, such as chalcocite $\left(\mathrm{Cu}_{2} \mathrm{~S}\right)$ and chalcopyrite $\left(\mathrm{CuFeS}_{2}\right)$. The oxidation of these carbonates cause the formation of some green crust of malachite $\left(\mathrm{Cu}_{2} \mathrm{CO}_{3}(\mathrm{OH})_{2}\right)$.

Quantitative information regarding the chemical analysis composition of the samples from the Draissa deposits is obtained using X-Ray Fluorescence (Table 1). The average content of raw material is $93.6 \% \mathrm{SiO}_{2}$. The composition is completed by the presence of $\mathrm{Al}_{2} \mathrm{O}_{3}, \mathrm{CaO}$ and $\mathrm{Fe}_{2} \mathrm{O}_{3}$ oxides in notable quantities. Feldspars and muscovite are the main hosts of $\mathrm{Al}^{3+}$ while calcite is the main mineral responsible for the presence of calcium. Muscovite crystals may also contain trace elements. Fe oxides (mainly hematite) contain the majority of the iron present in the rock, but some trace quantities can go in the structure of other minerals (quartz, carbonates, etc).

\section{Table 1 is here}

$\mathrm{XRF}$ analyses also reveal significant amounts of chlorine $(\mathrm{Cl})$. Aqueous fluid inclusions are very present in quartz. They can contain important amounts of salts that can be responsible for the presence of $\mathrm{Cl}^{-}, \mathrm{Ca}^{2+}, \mathrm{Mg}^{2+}, \mathrm{K}^{+}$, etc.

It has been observed that Draissa quartz is mostly associated with deep feldspar and other minerals such as mica hematite, dolomite, barite and iron oxides.

SIMS profile measurements are obtained in the $150 \times 150 \mu \mathrm{m}^{2}$ analysis area (Fig. 5). The highlighted elements are $\mathrm{O}, \mathrm{Si}, \mathrm{Al}, \mathrm{Cl}$ and $\mathrm{S}$.

Fig 5 is here 
Each element curve represents an accumulated intensity (total) obtained from approximately 100 $\mathrm{nm}$ depth inside the sample after sputtering time for $300 \mathrm{~s}$ using oxygen and cesium sources of energy respectively. The total intensities (TI) for each element using oxygen source are: O (TI: 22. $4 \times 10^{2}$ ), Si (TI: $10.01 \times 10^{2}$ ), $\mathrm{Al}$ (TI: $1.25 \times 10^{2}$ ) (Figure 5 a). For the quartz samples the values using Cesium source are: $\mathrm{Si}\left(\mathrm{TI}: 15.64 \times 10^{2}\right), \mathrm{Cl}$ (TI: $0.2 \times 10^{2}$ ), S (TI: $1.41 \times 10^{2}$ ) (Figure 5 b). The presence of deep elements such as oxygen $(\mathrm{O})$, silicon $(\mathrm{Si})$, aluminum $(\mathrm{Al})$, as well as sulfur $(\mathrm{S})$ and chlorine $(\mathrm{Cl})$ at the extreme surface is registered, which completes and confirms the results of the XRF analysis.

\subsection{Quartz valorization by reverse flotation process}

\subsection{Comminution}

Based on mineralogical and chemical studies of the Draissa samples, reverse flotation on laboratory scale is used as an adequate, dynamic multiphase and high efficiency selective process in order to remove the main impurities from siliceous gangue required as raw material for silicon and optical domains.

The feed containing mainly siliceous gangue (93-94\% quartz) associated to different other minerals (impurities) such as feldspar, mica and hematite carried out first, a comminution in order to achieve the required grain size of valuable mineral, which is $0.1 \mathrm{~mm}$ in our case. After the ground mineral undergo the flotation process.

After the comminution, some fine clay minerals are removed by desliming. The flow-sheet of the used process is represented in Fig. 6.

Fig. 6 is here 


\subsection{Mica removal}

As collector reagent the duodecyclamine (DDA) is used for the first stage. This reagent is well known for its very high absorption capacity on the surface of the ore thanks to the hydrogen bands formed from its polar groups [29-31]. The DDA reagent selectively makes the mica surface grains hydrophobic and thus confers a greater affinity for the gas phase than to the liquid phase. In order to study a degree of hydrophilicity of the whole of the gangue, the contact measuring angle between the liquid and solid phases is carried out. According to the Fig. 7, the mica surface is extremely hydrophilic (contact measurement angle around $0^{\circ}$ ), where the feldspar, quartz and iron have respectively the value $14^{\circ}$ and $10^{\circ}$ and $6^{\circ}$ (Fig. 7a).

\section{Fig 7 is here}

After adding DDA collector in the first stage, it is noted that at $\mathrm{pH}$ between 2-3 that the contact angle for the mica achieves the optimum rate $95 \%$, where the contact angles value of feldspar, quartz, and iron are very low, $25^{\circ}, 14^{\circ}$ and $6^{\circ}$ respectively (Fig. 7 b). These results indicate that the mica surface becomes strongly hydrophobic $\left(>90^{\circ}\right)$ and the rest of the gangue still mostly indicates hydrophilic interaction as a contact angle is less than $90^{\circ}$. We remark that the feldspar and the quartz values are little beat increased, that is means that no significant quantity of these minerals can be entrained with mica as concentrate. Consequently, the reagent allows the mica separation from the rest of the gangue, after which it will be carried away by the oxygen bubbles introduced than into the flotation cell towards the surface and by the frother agent as a concentrate. A pine oil as frother agent was added in order to maintain the life of the froth. After the flotation the concentration is analyzed in terms of minerals recoveries. The flotation recoveries of mica and the rest of the gangue as a function of DDA concentration at $\mathrm{pH} 2-3$ are 
shown in Fig. 8. It is noted that, at this value of $\mathrm{pH}$, reagent exhibits good collecting ability for mica and the recovery is well above $98 \%$ when its concentration is around $300 \mathrm{~g} / \mathrm{t}$, while the recovery of the gangue decreases rapidly. These results are in agreement with the literature. [32].

\section{Fig. 8 is here}

The tailings of mica flotation were dewatered and washed in order to remove the residual reagents on particles, which will be used for the following stage.

\subsection{Iron Oxides Minerals removal}

The standard iron minerals removing method which is mostly used in minerals processing is the reverse flotation using anionic collectors, such as fatty acid and petroleum sulfonate [33,34]. In our case the sodium oleate (NaOL) at $98 \%$ as anionic collector is chosen for its high selectivity of iron minerals compared to the rest of minerals gangue [35], where $\mathrm{H}_{2} \mathrm{SO}_{4}$ is used as activator and $\mathrm{pH}$ modifier, pine oil as a frothing agent. The collector dosage is changed from 100 to $300 \mathrm{~g} / \mathrm{t}$.

After flotation, the results show that a major quantity of oxides minerals, mainly hematite was removed (Fig. 9). This can be explained by the conversion of $\mathrm{Fe} 2+$ ions to $\mathrm{Fe} 3+$ ones through the surface dissolution which results in the formation of more insoluble ferric oleate in comparison with ferrous oleate compound, which reduces the zeta potential of hematite and consequently increases the chemical adsorption of oleate ions significantly.

However, during the iron minerals flotation, the reagent $\mathrm{NaOL}$ absorbs ions on silicate surfaces which are charged positively due to the presence of residual amine collector from mica flotation. This is due mainly through hydrocarbon tail-tail interactions, thus increasing their hydrophobicity, which can generate the feldspar and the quartz losses with iron oxide minerals 
concentrate. These results were also confirmed by the studies of $[29,36]$ In our case these losses are negligible around $1.75 \%$ for feldspar and $1.1 \%$ for quartz respectively.

\subsection{Feldspar removal}

Because of the difficulty to separate the feldspar from the quartz, mainly due to overlapping their densities, several studies have been done to solve this problem. Although the HF poses challenges in terms of health, safety, and environment, it still plays a determinant role during the quartz separation from feldspar. In this case, the $\mathrm{HF}$ is used instead of $\mathrm{H}_{2} \mathrm{O}_{4}$ for its high efficiency to obtain a very high grade product. Feldspar is activated using fluoride ions and floated using an amine acetate collector DDA and the pine oil as frother. In this context, $\mathrm{F}^{-}$ions activate feldspar from tailings by increasing their surface charge. The activator increases its own surface potential to prevent the production of hydrophiles, and also removed them from the concentrate. The obtained residual product represents high grade quartz.

During the flotation process, feldspar attaches to the bubbles due to its hydrophobic characteristics thanks to the HF effect which is used as an activator for feldspar and depressor for the quartz. The bubbles separate the feldspar from the quartz by carrying the grains to the upper part of the cell. HF in the role of depressor transforms strongly the quartz surface particles in hydrophilic ones. (HF) as activator creates a large difference in the mineral's zeta potentials. Thus, the zeta potential of feldspar becomes very negative while that of quartz approaches zero (Fig. 9).

At $\mathrm{pH}$ around 2.5 , it is noted that the floatability of feldspar significantly increases compared with that of the quartz (Fig. 9). This is due trough the increasing of electrostatic adsorption of the collector DDA on the feldspar surface which is already strongly negatively charged. Thus, effectively increased its hydrophobicity and makes the feldspars easily floatable. This conclusion 
is also confirmed by $[37,38]$. After, the quartz particles are moved towards of the bottom of the flotation cell. At the end of the process, the quartz is rinsing by hydrochloric acid $(\mathrm{HCl})$, filtered from the solution with deionized water, and dried.

The results of the investigations show that the recovery of feldspar in the concentrate 3 achieves an optimum rate of $99,8 \%$ (Fig. 10). That is mean that the selectivity of feldspar flotation reaches to maximum. Consequently, quasi no quartz till to $0.01 \mathrm{wt} \%$ is detected in the feldspar concentrate. This is mainly due to.the pretreated feldspar by HF in increasing its floatability compared to quartz, which is in agreement with the literature [37-39].

Fig. 9 is here

Fig. 10 is here

The final quartz concentration after flotation process characterized by XRF reaches $99.65 \mathrm{wt} \%$, which is available to be used as raw material for silicon production and also for some optical applications (Table 2).

Table 2 is here

\section{Conclusion}

The study of raw material from the Draissa Deposits (Algeria) reveals the presence of sandstones with high content of quartz. The X-ray fluorescence analyses highlight an initial $\mathrm{SiO}_{2}$ concentration of $93.6 \mathrm{wt} \%$, which is associated with other mineral phases (feldspar, mica, carbonates, sulfates and Fe oxides) that must be eliminated during the quartz purification process. 
In order to increase the required concentration of quartz $\left(99 \% \mathrm{SiO}_{2}\right)$ for silicon production and some optical applications, the reverse flotation process in three stages is used.

The effect of used reagents and the $\mathrm{pH}$ of pulp on the silica recovery and its concentration are obtained and discussed.

The flotation results show that the separation of mica from the rest of the gangue is feasible by using dodecylamine (DDA) as collector.

For the mica removal, at $\mathrm{pH}$ around 2, DDA reagent exhibits good collecting ability for mica and the recovery is above $98 \%$ when its concentration is around $300 \mathrm{~g} / \mathrm{t}$.

The use of sodium oleate amine $(\mathrm{NaOL})$ as collector at $98 \%$ concentration removes Fe-oxides (hematite). Using double actions dewatering/washing before second stage flotation allowed to minimize the feldspar and the quartz losses. About $1.8 \mathrm{wt} \%$ of feldspar and $1.1 \mathrm{wt} \%$ wt. of quartz are obtained respectively.

Using $\mathrm{HF}$ as activator reagent for feldspar and suppressant reagent for quartz improves the floatability of the feldspar and makes its separation from quartz easier, which increases the $\mathrm{SiO}_{2}$ concentration and grade.

The reverse flotation results show that the recovery rate of hematite, mica and feldspar achieves $97 \mathrm{wt} \%, 99 \mathrm{wt} \%$ and $99 \mathrm{wt} \%$ respectively, which presents a high viability of the chosen process.

The process used enhances silica concentration from $93-94 \mathrm{wt} \%$ to $99.65 \mathrm{wt} \%$ decreasing at the same time the impurities concentrations up to $0.001 \mathrm{wt} \% \mathrm{Fe}_{2} \mathrm{O}_{3}, 0.06 \mathrm{wt} \% \mathrm{Al}_{2} \mathrm{O}_{3}$ and $0.013 \mathrm{wt} \%$ $\mathrm{CaO}$ from initial feed containing $0.16 \mathrm{wt} \%, 5.74 \mathrm{wt} \%$ and $0.15 \mathrm{wt} \%$ respectively, which is suitable intermediate technological product for silicon production.

\section{Acknowledgements}


Funding was provided by the General Direction of research and development technologies/Ministry of Higher Education and Research Sciences DGRSDT/MERS (ALGERIA). We thank the CEO of Algerian Albaryte Company Mr. Ahmed Belhocine to authorize us for collecting the samples from the study area.

We would like to thank also Dr. Ould Hamou Malek for its precious help in the flotation process at Mining Engineering Department in the Ecole Polytechnique d'Alger. Raman analyses are performed at Ecole Normale Superieure of Lyon (ENS). The Raman facility in Lyon is supported by the "Institut de Science de l'Univers (INSU)". We are also grateful to Gilles Montagnac for assistance. Cathodoluminescence analyzes are performed at Lithos Center from Bucharest. We thank Izabela Mares for his help. We are grateful to Barbara Mattison for help with the English editing.

\section{References}

1. Kheloufi A, Bobocioiu E, Kerkar F, Kefaifi A, Anas S, Medjahed SA, Belkacem Y, Keffous A (2017). Optical and spectroscopic characterizations of Algerian silica raw material to predict high quality solar-grade silicon. $\mathrm{J}$ Opt Mat. https://doi.org/10.1016/j.optmat.2016.09.063

2. 2.Hu J, BandoY, Zhan J, Yuan X, Sekiguchi T, Golberg, 2005 Self-Assembly of $\mathrm{SiO} 2$ Nanowires and Si Microwires into Hierarchical Heterostructures on a Large Scale $\uparrow$. J adv Mat. https://doi.org/10.1002/adma.200401789

3. Li J, Li X, Shen Q, Zhang Z, Du F (2010) Further purification of industrial quartz by much milder conditions and a harmless method. J. Environ. Sci. Technol. https://doi.org/10.1021/es101104c.

4. Shapiro B, Adhikari R, Aguiar O, Bonilla E, Fan D, Gan L, Gomez I, Khandelwal S (2017) Cryogenically cooled ultra low vibration silicon mirrors for gravitational wave observatories. Cryog. https://doi.org/10.1016/j.cryogenics.2016.12.004 
5. Huang H, Li J, Li X, Zhang Z (2013) Iron removal from extremely fine quartz and its kinetics. J Sep and Pur Tech. https://doi.org/10.1016/j.seppur.2013.01.046

6. Mowla D, Karimi G, Ostadnezhad K (2008) Removal of hematite from silica sand ore by reverse flotation technique. J Sep and Pur Tech. https:// 10.1016/j.seppur.2007.08.023

7. Taxiarchou M, Panias D, Douni I, Paspaliaris I, Kontopoulos A (1997) Removal of iron from silica sand by leaching with oxalic acid. J Hydrom. https://doi.org/10.1016/S0304386X(97)00015-7

8. Farmer AD, Collings A.F, Jameson G (2000) The application of power ultrasound to the surface cleaning of silica and heavy mineral sand. J Ultrason Sonochem 7: 243-247

9. Pavlovic S, Brandao PRG (2003) Adsorption of starch, amylose, amylopectin and glucose monomer and their effect on the flotation of hematite and quartz. J Miner Eng. https:// doi:10.1016/j.mineng.2003.06.011

10. Yuhua W, Jianwei R (2005) The flotation of quartz from iron minerals with a combined quaternary ammonium salt. Int J Miner. Proc. 77, 2, 116-122. https://doi.org/10.1016/j.minpro.2005.03.001

11. Quast K (2006) Flotation of hematite using C6-C18 saturated fatty acids. J Miner Eng. https://doi.org/10.1016/j.mineng.2005.09.010

12. Veglio F, Passariello B, Barbaro M, Plescia P, Marabini AM (1997) Drum leaching tests in iron removal from quartz using oxalic and sulphuric acids. Int $\mathrm{J}$ Mine. Process. https://doi.org/10.1016/S0301-7516(98)00014-3

13. Kayal, N, \& Singh N (2007) Stepwise complexometric determination of aluminium, titanium and iron concentrations in silica sand and allied materials. Chem Cent J., https://doi.org/10.1186/1752-153x-1-24

14. Veglio F, Passariello B, Abbruzzese C (1998) Iron removal process for high-purity silica sands production by oxalic leaching, Ind. Eng. Chem. Res. https:// https://doi.org/10.1021/ie990156b

15. Miettinen T, Ralston J, Fornasiero D (2010). The limits of fine particle flotation. J Min Eng. https//doi.org/ 10.1016/j.mineng.2009.12.006

16. Martínez-Luévanos A, Rodríguez-Delgado M G, Uribe-Salas A, Carrillo Pedroza FR, OsunaAlarcón JG (2011) Leaching kinetics of iron from low grade kaolin by oxalic acid solutions. J App. Clay Sci. https://doi.org/10.1016/j.clay.2011.01.011 
17. Leistner T, Peuker, U A, Rudolph M (2017) How gangue particle size can affect the recovery of ultrafine and fine particles during froth flotation. $J$ Min Eng. https://doi.org/10.1016/j.mineng.2017.02.005

18. Mandal SK, Banerjee PC (2004) Iron leaching from China clay with oxalic acid: effect of different physic-chemical parameters. Int J Min Proc. https://doi.org/10.1016/j.minpro.2004.01.004

19. Lee SO, Tran T, Park YY, Kim SJ, Kim M J (2006) Study on the kinetics of iron oxide leaching by oxalic acid. Int J Min. Proc. https:// DOI: 10.1016/j.minpro.2006.03.012

20. Du F, Li J, Li X, Zhang Z (2011) Improvement of iron removal from silica sand using ultrasound-assisted oxalic acid. J Ultrason Sonochem. https://doi: 10.1016/j.ultsonch.2010.07.006

21. Raman, V, Abbas A (2008) Experimental investigation on ultrasound mediated particle breakage. J Ultrason Sonochem. 15: 55-64

22. Mgaidi A., Jendoubi F, Oulahna, D, Maaoui M E, Dodds J A (2004) Kinetics of the dissolution of sand into alkaline solutions: application of a modified shrinking core model. J Hydrom. https://doi.org/10.1016/S0304-386X(03)00117-8

23. Liou TH (2004) Kinetics study of thermal decomposition of electronic packaging material Chem Eng J. https:// doi.org/10.1016/S1385-8947(03)00181-5

24. Wang L, Peng Y, Runge K, Bradshaw D (2015) A review of entrainment: Mechanisms, contributing factors and modelling in flotation. Min Eng J. https:// doi.org/10.1016/j.mineng.2014.09.003

25. Rapport sur les travaux d'exploration de la barite de la région de Draissa (2013) EPE ORGM Spa. https://gprgindonesia.wordpress.com/geologicalsetting-of-algeria. (Accessed July 4th 2013)

26. Anas S, Kheloufi A, Boutarek Zaourar N (2017) Characterization of impurities present on Tihimatine (Hoggar) Quartz, Algeria, J of Afr Earth Sci. https://10.1016/j.jafrearsci.2017.09.001

27. Götze J, Plötze M, D, Habermann S (2001) Cathodoluminescence (CL) of quartz: origin, spectral characteristics and practical applications. J Mineral Petrol Miner. and Petr. https://doi.org/10.1007/s007100170040 
28. Muller A, Wanvik J E, Ihlen PM (2012) Deposits, mineralogy and analytics, Springer Geology, Petrological and chemical characterization of high-purity quartz deposits with example from Norway, in Quartz: deposit, mineralogy and analytic, springer Geology

29. Filippov L O, Severov VV, Filippova I (2014) An overview of the beneficiation of iron ores via reverse cationic flotation. J Min proc. https//doi.org/10.1016/j.minpro.2014.01.002

30. Sanjeet Kumar Suman, Shravan Kumar (2020) Reverse flotation studies on iron ore slime by the synergistic effect of cationic collectors. Sep Sci and Tech J. https//doi.org/ 10.1080/01496395.2019.1604757

31. Lelis D F, Da Cruz, D G, Fernandes Lima R M (2019) Effects of Calcium and Chloride Ions in Iron Ore Reverse Cationic Flotation: Fundamental Studies. Min Proc and Extr Metall R. https://doi.org/10.1080/08827508.2019.1666122

32. Wang Li, Sun W, Liu R (2014) Mechanism of separating muscovite and quartz by flotation. J of Cent Sou Univ . https://doi.org/10.1007/s11771-014-2341-5

33. Gulsoy O Y, Can N M, Bayraktar I, Ersayin S, Hizal M, Sahin A I (2004) Two stage flotation of sodium feldspar-From laboratory to industrial application. Min Proc and Extr Metal 113: $139-144$

34. Li Wang, Mengjie Tian, Sultan Ahmed Khoso, Yuehua Hu, Wei Sun, Zhiyong Gao (2019) Improved Flotation Separation of Apatite from Calcite with Benzohydroxamic Acid Collector,. Min Proc and Extr Met https:// doi.org/ 10.1080/08827508.2019.1666126

35. Heyes G W, Allan G C, Bruckard W J, Sparrow G J (2012) Review of flotation of feldspar. Min Proc and Ext Met J. https:// doi.org/10.1179/1743285512y.0000000004

36. Hanumantha K, Rao, K S, Forssberg E. (1997) Mixed collector systems in flotation. Int J Min Proc. https://doi.org/10.1016/S0301-7516(97)00039-2

37. Orhan E C, Bayraktar I (2006) Amine-oleate interactions in feldspar flotation. J Min Eng. https://doi.org/10.1016/j.mineng.2005.06.001

38. Wang W, Cong J, Deng J., Weng X, Lin Y, Huang Y, Peng T (2018) J Min, https://doi.org/10.3390/min8040149

39. Larsen E, Kleiv R A (2016) Flotation of quartz from quartz-feldspar mixtures by the HF. J Min Eng. https://doi.org/10.1016/j.mineng.2016.07.021 
